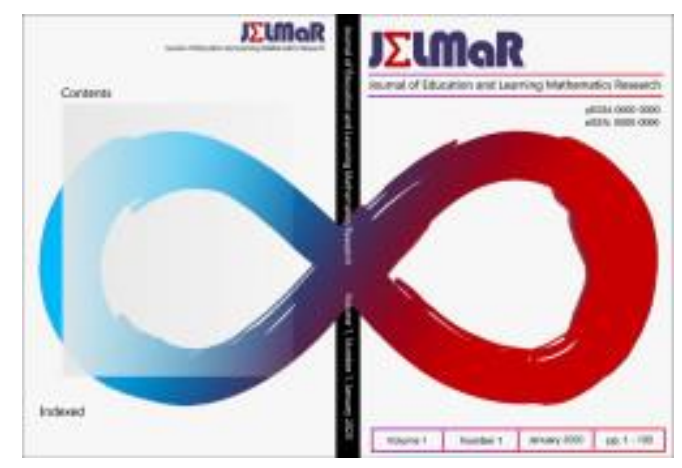

Journal of Education and Learning Mathematics Research (JELMaR)

Online ISSN $\quad:$ 2715-9787

Print ISSN : :2715-8535

Journal Homepage : http://jelmar.wisnuwardhana.ac.id/index.php/jelmar/index

\title{
Development of Learning Outcome Assessment Instruments with Mathematics Communication Ability in High School Mathematics Learning
}

\section{Dewi Nasiroh}

To cite this article: Nasiroh, D. (2021). Development of Learning Outcome Assessment Instruments with Mathematics Communication Ability in High School Mathematics Learning. Journal of Education and Learning Mathematics Research (JELMaR), 2(2), 26-33. https://doi.org/10.37303/jelmar.v2i2.58

To link this article : https://doi.org/10.37303/jelmar.v2i2.58

\section{Publisher}

Department of Mathematics Education,

Faculty of Teacher Training and Education,

Universitas Wisnuwardhana Malang 


\title{
Development of Learning Outcome Assessment Instruments with Mathematics Communication Ability in High School Mathematics Learning
}

\author{
Dewi Nasiroh \\ Research of Education, Graduate School of Universitas Negeri Yogyakarta, Indonesia \\ Email: dewinasiroh06@gmail.com
}

\begin{abstract}
This study (1) develop a learning assessment instrument with the assignment technique-oriented to mathematical communication ability in high school mathematics of trigonometry material (2) reveal the feasibility of the developed instrument, (3) reveal the characteristics of the developed instrument, (4) reveal the users' responses to the instrument, (5) measure the ability of mathematical communication of the students on high school mathematics in learning trigonometry. This study was research and development using the procedure of tests preparation based on Mardapi (2017) with the steps including preparing test specifications, writing test questions, reviewing tests, administering tests, analyzing tests items, improving the tests, assembling the tests, administering the tests and interpreting results. The initial product was field-tested to 254 students of high schools in Yogyakarta City. The result of the research was an assessment instrument of learning outcomes with assignment technique-oriented to the mathematical communication ability in high school mathematics learning of trigonometry. The Aiken index was 0.7 for this instrument, and the instrument was reliably tested to a test of participants with the ability $(q)$ between -4.07 logits $<q<3.79$ logits. The teachers' responses to test instruments were good. The results of field trials showed that 20 items fit with the PCM model. The level of difficulty was in the range of -1.29 logits $<b<1.32$ logits. The function of the test information Obtained by $q=-0.11$ logit and the standard error of measurement was 0:18. The measurement result of 90 students shows that the student's mathematical communication ability was $67 \%$.
\end{abstract}

Keywords: assessment, instrument, mathematical, trigonometry

\section{INTRODUCTION}

National education according to the Law of the Republic of Indonesia Number 20 of 2003 is a conscious and planned effort to create a learning atmosphere and learning process so that students actively develop their potential to have religious-spiritual strength, selfcontrol, personality, intelligence, noble character, and skills. needed by himself, society, nation, and state. Improving the quality of education is expected to prepare graduates to be able to compete globally. Elucidation of Article 35 of Law Number 20 of 2003 states that graduate competency standards are qualifications of graduates' abilities that include the attitudes, knowledge, and skills of students that must be fulfilled or achieved from an educational unit at the primary and secondary education levels. Based on this, knowledge is one of the qualifications of abilities that need to be measured for success. Concerning knowledge competence, education is carried out in teaching and learning activities in formal and non-formal schools including learning mathematics. By the standards of the National Council of Teaching Mathematics (NCTM) (2000: 29), the purpose of mathematics learning should facilitate the ability of problem-solving, the ability of reasoning, communication skills, the ability of the connection, and the ability of representation. Referring to the learning objectives of mathematics in content standards and mathematics 
learning standards according to the NCTM, the ability that students need to develop and master is mathematical communication. The mathematical communication of students in Indonesia is still categorized at a low level, this is evidenced by the results of the Trend in International Mathematics and Science Study (TIMMS) in 2015, Indonesia is ranked 5th from the bottom with a score of 397, and is below the average level. Learning mathematics in its implementation involves mathematical communication skills. The implementation of the learning carried out can be measured its success through assessment, this is as stated by Arikunto (2015: 19), one of the objectives of the assessment is as a measure of success. According to Kunandar (2014: 64), one of the problems in assessing learning outcomes in schools is that the quality of the instruments or questions produced is still not valid and reliable, because the writing is done in a hurry. the quality of the assignment assessment instrument has not developed much and the quality is not yet known, both from the aspect of validity and reliability and is far from the orientation of mathematical communication skills. Therefore, it is necessary to develop an instrument for assessing learning outcomes with assignment techniques oriented to mathematical communication in high school mathematics learning, especially in trigonometry material.

\section{METHOD}

This type of research includes development research, in which researchers develop instruments to measure students' mathematical communication skills. This research produces a product in the form of an instrument that can be used as an example or reference by the teacher to be able to measure mathematical communication.

Instrumental trials and measurements of mathematical communication skills were carried out at Yogyakarta State High School 1, Yogyakarta State High School 3, Yogyakarta State Senior High School 6, Yogyakarta State High School 7 and Yogyakarta State High School 8. The research subjects were high school students in class X. The subjects of the research trial were 254 students at Yogyakarta State Senior High Schools and 90 students for the measurement subjects.

The development model in this study is based on an instrument development model in the form of a test based on Mardhapi (2017: 95-113) with steps including compiling test specifications, writing test questions, studying tests, conducting test trials, analyzing items, improving tests, assembling tests. , administer the test, and interpret the test results.

The product trial design in this study used a descriptive design with the stages of expert judgment trial, instrument trial, product quality assessment by reviewers, and measurement.

Data collection techniques in the form of tests and non-tests. The test technique uses an assessment instrument while the non-test technique uses a questionnaire. The quality of the assessment instrument is known from the collection of data on the results of field tests from students in several schools. The quality of a good test instrument is known based on the validity of the content, construct, and function of the test information. Furthermore, this test technique is also used at the stage of measuring abilities which will later be measured. The questionnaire technique was carried out by collecting data using instruments in the form of validation sheets and questionnaires for user responses to assessment instruments. The validation sheet is filled out by the expert judgment and the response questionnaire is filled out by the teacher who has used the instrument. 


\section{RESULT AND DISCUSSION}

This development resulted in an assessment instrument consisting of 20 descriptive questions on trigonometric material. The results of the validation by expert judgment were analyzed by Aiken's V and the result was 0.70 . This means that the items in this assessment instrument are valid. Test assumptions that must be met in the analysis using the Rasch model include (1) unidimensional test, the trigonometric test instrument contains 10 eigenvalues that have a value of more than 1 . The number of factors contained in the instrument can be known from the scree plot (Retnawati, 2014: 47). This means that there are 10 factors formed. These ten factors can explain about $82.123 \%$ of the total variance (2) local independence test The results of the analysis of the local independence assumption test are in the form of a covariance matrix which shows that the number under the diagonal line is 0 , then the questions are not related and (3) the item parameter invariance test and ability

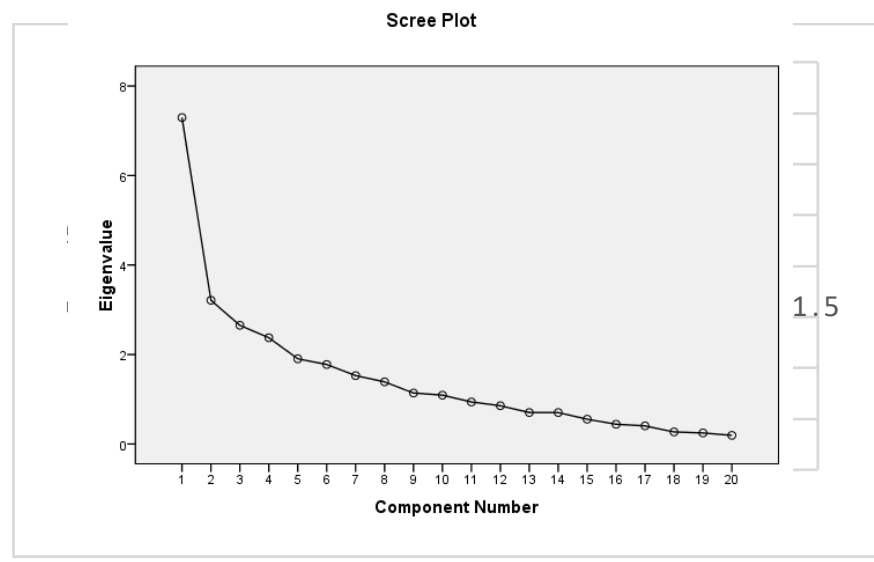

Figure 2. Invariance of Item Parameters

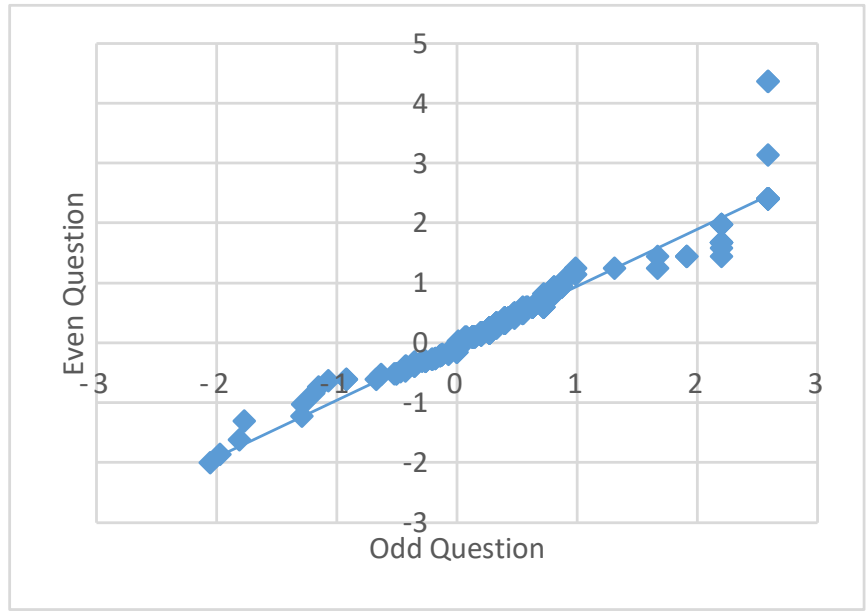

Figure 3. Invariance of Ability Parameters 
The next product assessment is carried out by the mathematics teacher using an instrument user assessment questionnaire. The results of the responses by the teacher are presented in Table 1

Table 1. Assessment of Instruments by Teachers

\begin{tabular}{llll}
\hline No. & Aspect & Average score & Category \\
\hline 1 & Substance & 4.04 & Good \\
\hline 2 & Construction & 4 & Good \\
\hline 3 & language & 4.08 & Good \\
\hline 4 & Practicality & 4 & Good \\
\hline
\end{tabular}

Testing of items fit for the test as a whole by Adam \& Khoo (Istiyono, Mardhapi, and Suparno, 2014: 120) based on the value of the average INFIT Mean of Square (Mean INFITMNSQ) and its deviation default. If the mean INFIT MNSQ is about 1.0, then the overall test is fit with the model.

Table 2. Item Fit

\begin{tabular}{|c|c|c|}
\hline \multirow{2}{*}{$\begin{array}{c}\text { Entry } \\
\text { Number }\end{array}$} & \multicolumn{2}{|c|}{ Infit } \\
\hline & MNSQ & ZSTD \\
\hline 19 & 0.93 & -0.5 \\
\hline 18 & 0.75 & -3.6 \\
\hline 20 & 0.97 & -0.4 \\
\hline 6 & 1.10 & 1.3 \\
\hline 9 & 1.01 & 0.1 \\
\hline 14 & 1.13 & 1.9 \\
\hline 4 & 1.12 & 1.7 \\
\hline 17 & 1.11 & 1.5 \\
\hline 15 & 0.86 & -1.9 \\
\hline 16 & 1.08 & 1.1 \\
\hline 13 & 1.12 & 1.6 \\
\hline 7 & 0.90 & -1.2 \\
\hline 10 & 1.09 & 1.0 \\
\hline 11 & 0.88 & -1.2 \\
\hline 5 & 0.81 & -2.2 \\
\hline 3 & 0.82 & -1.9 \\
\hline 12 & 1.02 & 0.2 \\
\hline 8 & 1.38 & 2.9 \\
\hline 1 & 1.11 & 1.0 \\
\hline 2 & 1.08 & 0.7 \\
\hline MEAN & 1.01 & 0.1 \\
\hline SD & 0.15 & 1.6 \\
\hline
\end{tabular}


Based on Table 2, the value of the average INFITMNSQ is 1.01 (about 1) and the deviation standard 0.15 (about 0.0 ), then the overall test in the form of descriptions fit with the model of PCM 1 PL.

The item difficulty parameter (b) is a description of the level of difficulty of an item expressed in logit units. Retnawati (2014: 114) revealed that the level of item difficulty is one of the item parameters that are very useful for analyzing a test because by looking at the item parameters, the quality of the item will be known.

The difficulty level of each category is obtained based on PCM. The data obtained from the students' work are analyzed and the measured value is obtained at the output item entry. Based on the item entry output data, it can be seen the level of difficulty of each item. Adedoyin \& Mokobi (2013: 1001) state that an item is said to be easy if the $b$ value is less than -1 logit, the category is moderate if it is between -1 to one 1 , and the category is difficult if it is more than 1 .

Table 3. Item Difficulty Level

\begin{tabular}{ccc}
\hline \multicolumn{2}{c}{ Entry } & \multirow{2}{*}{ Category } \\
\cline { 1 - 2 } Number & Measure & \\
\hline 19 & 1.32 & Very difficult \\
\hline 18 & 0.79 & Medium \\
\hline 20 & 0.70 & Medium \\
\hline 6 & 0.51 & Medium \\
\hline 9 & 0.38 & Medium \\
\hline 14 & 0.35 & Medium \\
\hline 4 & 0.32 & Medium \\
\hline 17 & 0.30 & Medium \\
\hline 15 & 0.26 & Medium \\
\hline 16 & 0.20 & Medium \\
\hline 13 & 0.16 & Medium \\
\hline 7 & -0.16 & Medium \\
\hline 10 & -0.18 & Medium \\
\hline 11 & -0.24 & Medium \\
\hline 5 & -0.35 & Medium \\
\hline 3 & -0.61 & Medium \\
\hline 12 & -0.77 & Medium \\
\hline 8 & -0.85 & Medium \\
\hline 1 & -0.85 & Medium \\
\hline 2 & -1.29 & Easy \\
\hline MEAN & 0.00 & \\
\hline SD & 0.63 & \\
\hline & & \\
\hline
\end{tabular}

The test information function is the strength of the test in revealing the abilities measured by the instrument. Function test information will vary according to the value of $q$ ( ability ) learners. On the value of q particular, the value of the information function will 
achieve the maximum value. The maximum point indicates that if the item is done by learners with q particular, it will obtain the highest information (Dragon, 1992: 324).

The test information function provides a more accurate measure of estimating the ability of test-takers than the reliability coefficient (Samejima, 1994: 229). The TIF curve for educational tests is generally bell-shaped with the maximum amount of information near a certain point (DePascale \& Dunn, 2008: 2). The ability of test-takers is on the vertical axis. The higher the peak of the test information function, the higher the reliability of measurement.

Based on the calculations, the maximum value of the information function test device at 32.11 which is located on the ability of the test taker with $q=-0.11$, function test information that is located on a logit obtained an error rate measurement (SEM) of 0.18. The data means that the instrument has effectiveness for measuring mathematical communication skills of 32.11 with a measurement error rate of 0.18 .

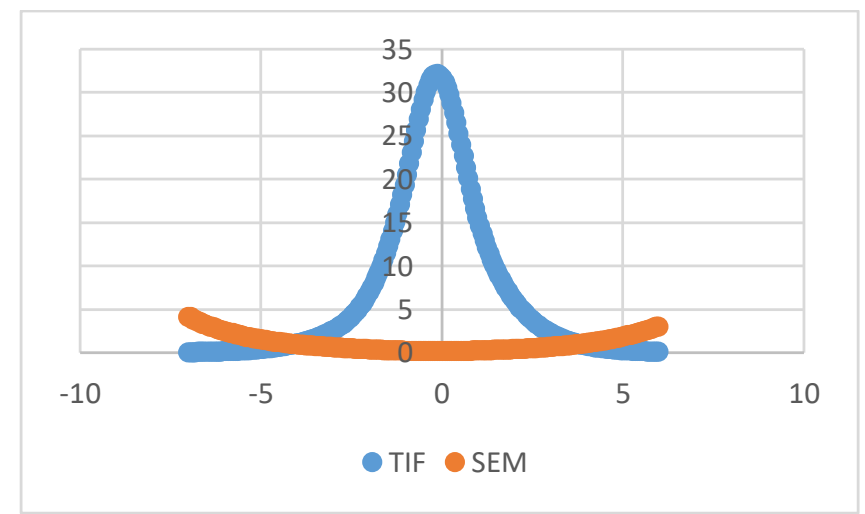

Figure 4. TIF and SEM Curves

Based on the curve between TIF and SEM, the point of intersection between the curve and SEM TIF is at a value $q=-4.07$ and $q=3.79$. It provides information that is reliable if the instrument was tested in the test participants who have the ability in the range of $4.07<\mathrm{q}<3.79$. Therefore, this instrument is reliable if it is tested on test-takers with low, medium, or high abilities.

The measurement stage uses items that have been analyzed and revised and then reassembled into a valid and empirically reliable test. This test was given to 90 students from three schools in the city of Yogyakarta with the results of mathematical communication skills of $67 \%$ included in the medium category.

\section{CONCLUSION}

Based on the results of the analysis that has been carried out, it can be concluded several things as follows:

1. The learning outcome assessment instrument with assignment technique-oriented mathematical communication skills in high school mathematics learning trigonometry material based on the validator's assessment and declared suitable for use with an average content validity index of 0.7 .

2. Learning outcome assessment instruments with the technique-oriented assignment of mathematical communication skills in mathematics trigonometry material 
consists of 20 questions describing the fit (fit) with the Partial Credit Model. This instrument is reliable when tested on the test participants who have the ability in the range of -4.07 logit $<q<3.79$ logits and level of difficulty of items that are in the range of -1.29 logit $<b<1.32$ logit

3. The teacher's assessment of learning outcomes assessment instruments with assignment techniques oriented mathematical communication skills in high school/MA mathematics learning on trigonometric material on aspects of substance, construction, language, and practicality is in a good category.

4. The results of the measurement of mathematical communication skills of $67 \%$ are included in the medium category.

Suggestions that can be given related to the product development of this assessment instrument include:

Mathematics teachers can use this instrument product to measure students' mathematical communication skills in high school in basic competencies 4.7 to 4.11 on trigonometry material. The product of this assessment instrument can be used as an example of modeling by high school mathematics teachers to develop measurement instruments on other materials.

\section{REFERENCES}

Adedoyin, O. O., \& Mokobi, T. (2013). Using irt psycometric analysisi ini examining the quality of junior certificate mathematics multiple choice examination test items. Internasional Journal of Asian Social Science, 3(4), 992-1011. Retrieved: https:/ / pdfs.semanticscholar.org/64e2/6548761a8af0c9936d1cf683531e01739a8 1.pdf

Arikunto, S. (2015). Dasar-Dasar Evaluasi Pendidikan (Edisi 2). Jakarta: Bumi Aksara.

DePascale, C. A, Dunn, J. (2008). Simplifying Psychomertics With SAS. NESUG. Retrieved: https://www.lexjansen.com/nesug/nesug08/ap/ap07.pdf

Istiyono, E., Mardhapi, D., \& Suparno. (2014). Penerapan Partial Credit Model Pada Tes Pilihan Ganda Termodifikasi Merupakan Model Alternatif Asesmen Fisika Yang Adil. Prosiding Konferensi Ilmiah Tahunann Himpunan Evaluasi Pendidikan Indonesia (HEPI) tahun 2014. 115-127.

Kunandar. (2014). Penilaian Autentik (Penilaian Hasil Belajar Peserta Didik Berdasarkan Kurikulum 2013). Jakarta: Rajawali Pers.

Mardhapi. D. (2017). Pengukuran, Penilaian Dan Evaluasi Pendidikan. Yogyakarta: Parama Publishing.

Naga, D.S. (1992). Pengantar Teori Skor Pada Pengukuran Pendidikan. Jakarta: Gunadarma.

NCTM. (2000). Principles And Standards For School Mathematics. Reston, VA: NCTM.

R. Rosnawati, Kartowagiran, \& Jailani. (2015). A formative assessment model of critical thinking in mathematics learning in junior high school. Reasearch and Evaluation in Educational Journal. Volume 1, Number 2, 186-198. Retrieved from : http//journal.uny.ac.id/index.php/reid

Republik Indonesia. (2003). Undang-Undang Nomor 20 Tahun 2003, tentang Sistem Pendidikan Nasional

Retnawati. (2014). Teori Respon Butir Dan Penerapannya. Yogyakarta: Parama Publishing. Samejima, F. (1994). Estimation of Reliability Coefficients Using The Test Information Function And Its Modifications. Applied Psycological Measurement, 18 (3), 229-244. Retrieved from https://conservancy.umn.edu/bitstream/handle/11299/117019/v18n3p229.p df?sequence $=1$ 
Samritin, S., \& Suryanto, S. (2016). Developing An Assessment Instrument Of Junior High School Students' Higher Order Thingking Skills In Mathematics. Research and Evaluation in Education, 2(1), 92-107. Retrieved: http:/ / dx.doi.org/10.21831/reid.v2il.8268. 